\title{
DEVELOPMENT OF ECONOMIC CYCLES IN THE CONTEXT OF GLOBAL CHANGES
}

\section{Olena Tkaczenko}

Associate Professor, DSc, Kyiv National Economic University named after Vadym Hetman, e-mail: olena.vadumivna@ukr.net, orcid.org/0000-0003-2923-7186, Ukraine

\section{Mariia Drobiazko}

Doctorant, PhD, Kyiv National Economic University named after Vadym Hetman, e-mail: mariadrobyazko@gmail.com, orcid.org/0000-0003-2427-7496, Ukraina

Annotation. In this article, a retrospective analysis of the theory of cyclicity is carried out and approaches to the study of cycles and crises are systematized. The scientists' observations regarding the identification of the global crisis of 2008-2009 as global are revealed and summarized. It is noted that the latest crisis of 2008-2009 was a consequence of the accumulation of both traditional problems of economic cyclicality and new emerging paradigmatic changes in world development in the conditions of globalization. The focus is on such contradictions of globalization as: technoglobalism, global stratification, global financial liberalization and market fundamentalism.

Keywords: cyclical economic development, economic cycles, globalization, global structural imbalances, global economic crisis, systemic crisis.

\section{DOI: http://dx.doi.org/10.23856/2809}

\section{Problematyka}

Kluczowym problemem w naukowym teoretycznym badaniu jest analiza dynamiki rozwoju gospodarczego świata w warunkach globalizacji. Na pytanie dokąd zmierza światowa gospodarka, czy czeka na nią kolejny kryzys gospodarczy i jakie będą jego konsekwencje - szukają odpowiedzi nie tylko ekonomiści, ale i socjologowie, matematykicybernetyki, filozofowie, urzędnicy, politycy.

Rozwiązanie tego zadania w dużej mierze zależy od identyfikacji na tle globalnego kryzysu finansowo-gospodarczego lat 2008-2009, uogólnienie przyczyn i identyfikacji mechanizmów, co jego uruchomiły. Do tego, niestety, nie wystarczy używać tylko wieloletnich teoretycznych i metodologicznych wypracowań teorii cyklu i kryzysów, co z kolei wymaga opracowania nowych, niestandardowych metod do badania etymologii zjawisk kryzysowych XXI wieku. Kształtowanie się koncepcji cyklicznego rozwoju w warunkach globalizacji pozwoli nie tylko przewidywać nowe zjawiska kryzysowe, ale i zrobić kolejny krok do budowania efektywnego modelu antykryzysowej regulacji.

\section{Retrospektywna analiza teorii cykli i kryzysów}

Pierwszy udokumentowany kryzys gospodarczy miał miejsce w imperium Rzymskim jeszcze w 33 roku p.n.e., ale początkiem badania procesów kryzysowych, zdaniem znanego amerykańsiego badacza cykli i kryzysów W. Mitchella, jest 1819 rok, kiedy ukazała się w pracy S. Sysmondy "Nowe zasady ekonomii politycznej". Od tego czasu, prawie 200 letni okres, powstał paradygmat cyklu rozwoju społeczeństwa, który opiera się na szeregu teorii, punktów widzenia przedstawicieli różnych kierunków i szkół nauk ekonomicznych. Pomimo 
różnic w podejściach metodologicznych do badania problematyki cyklu, wśród jej badaczy należy zaznaczyć takich wybitnych uczonych, jak: J-B. Say, W. Jevons, T. Malthus, K. Juglar, K. Marks, M. Kondratiew, M. Tuhan-Baranowski, S. Kuzniets, J. M. Clarke, P. Sorokin, A. Pigou, W. Mitchell, J.Schumpenter, M. Friedman, F. Hayek, Ch. Hansen, J. Hicks, G. Cassel, K. Wicksell, W. Foster, E. Mansfield, H. Mensch, R. Hawtrey i inne... Ich osiągnięcia naukowe $\mathrm{w}$ dużej mierze określiły podstawowe teoretyczne podstawy tego problemu i podstawowe treści ogólnie przyjętych obecnie teorii cykli i kryzysów w ramach tak zwanego głównego nurtu nauk ekonomicznych.

Wielość teorii cykli koniunkturalnych wymaga ich uogólnień, systematyzacji z odbiciem dynamiki przemian, kluczowych czynników, charakteru, przebiegu i skutków. Jednym z najstarszych i najbardziej rozpowszechnionych podejść do takiej systematyzacji jest tak zwany trzy cykliczny schemat J. Schumpetera, który opiera się na kryterium czasu trwania cykli. Odpowiednio cykle dzielą się na długie, średnie i krótkie, które nie są jeszcze znane pod nazwą naukowców, którzy poświęcili im odpowiednie badania. To długie cykle Kondratiewa (50-60 lat); średni Juglara, krótkie Kitchina (3 lata 4 miesięce). Rozwijając tą klasyfikację, już inni naukowcy uzupełniają jeszcze szeregiem innych cykli, w szczególności: rolniczy cykle (do 1 roku); cykle inwestycyjne S. Kuznietsa (18-25 lat); formacyjne cykle M. Evans (110 lat); polityczne cykle J. Modelskiego (90-120 lat); wiekowe fali F. Braudela (100-150 lat); cykle cywilizacyjne J. Forestera (200 lat); cykle-epoki E. Tofflera (1000-2000 lat).

Ponieważ przy badaniu dynamiki rozwoju społeczno-gospodarczego systemu nie wystarczy analizować tylko ilościowe parametry (w szczególności długość/częstotliwość cyklicznych wahań), to należy wziąć pod uwagę również wysokiej jakości bogactwo cykli gospodarczych, czyli przyczyny i mechanizmy, które je uruchomiły. A zatem głównym problemem każdego cyklicznego modelu staje się pytanie o przyczyny cykli. Według tego kryterium, istnieją dwa podejścia do wyjaśnienia przyczynowości cykli: endogenne i egzogenne teorii cykli lub tak zwane internalne i eksternalne teorii cykli. Endogenne koncepcji szukają przyczyny wewnątrz znaczącej specyfiki cykli (internalne teorii), a egzogenne (eksternalne teorii) - wyjaśniają cykle czynnikami zewnętrznymi. Egzogenne podejście dominowało na początkowych etapach badania problematyki cykli. Na przykład, W. Jevons i W. Wernadski thumaczyli cykle aktywności słonecznej, co prowadzi do pogorszenia sytuacji w rolnictwie i ogólnego spowolnienia gospodarczego; T. Malthus łączył ich z wyprzedzającymi tempami wzrostu populacji w porównaniu z przyrostem środków do życia; J. Mill tłumaczył ich przyczynę wojnami; wśród innych przyczyn wyróżniają się rewolucji i inne wstrząsy polityczne; rozwój nowych obszarów i związane z tym migracji. Takie podejście wyraźnie "odradza się" w ostatnim okresie, zwłaszcza pod wpływem światowego kryzysu lat 2008-2009 i zdarzeń, które nastąpiły po nim. Jego badania świadczą o istotnym wpływie cywilizacyjnych, instytucjonalnych, społecznych, a nawet politycznych czynników. Jak zauważa N. Osipow to "... kryzys epoki ogólnego kryzysu gospodarczego cywilizacji, to ten sam kryzys, który, z jednej strony, powoduje ogólnym kryzysem gospodarczym cywilizacji, a $\mathrm{z}$ drugiej, za pomocą którego cywilizacja gospodarcza próbuje swój ogólny kryzys przezwyciężyć" (Osipow, 2008).

$\mathrm{Z}$ przejściem do industrializacji $\mathrm{w}$ wiodących gospodarkach składają się korzystne warunki dla ekonomicznego rozkwitu, w tym dzięki naukowo-technicznemu postępu, co znacznie zwiększyło wydajność pracy i skali produkcji, ale bezpośrednią konsekwencją tego są kryzysy gospodarcze. Tak jak sferą powstania i rozprzestrzeniania się zjawisk kryzysowych stał się właśnie przemysł, szczególną formą społeczno-ekonomicznego cyklu 
staje się śródokresowy przemysłowy cykl. Pierwszym kryzysem tego cyklu stał się kryzys 1825 roku, który odbył się w Anglii, gdzie przemysłowy przewrót rozpoczął się wcześniej niż w innych krajach, a pierwotna akumulacja kapitału przeprowadzona w klasycznej formie. To właśnie jej analiza stała się podstawą marksistowskiej teorii kryzysów gospodarczych (teoria kapitalistycznej nadprodukcji), która wyjaśnia ich nadmierną akumulację kapitału we wszystkich trzech funkcjonalnych formach: towarowej, produkcyjnej i finansowej.

Naukowcy-ekonomiści zaczynają zwracać większą uwagę na endogeniczną koncepcję analizy czynników generowanych przez funkcjonowanie systemu gospodarczego. Tak, w teorii częstotliwości kryzysów przemysłowych M. Tuhan-Baranowskiego chodzi o uznaniu wiodącej roli inwestycji w rozwoju cyklu i szczegółowe podstawy inwestycyjnej teorii cyklu, zgodnie z którą fazy przemysłowego cyklu określone aktywnością inwestycyjną. Pomysł M. Tuhan-Baranowskiego o "oszczędności-inwestycje" jako główną siłę napędową aktywności gospodarczej, pozytywnie przyjął J. Keynes. Sam J. Keynes, wprowadził makroekonomiczną koncepcję, która tłumaczyła cykliczny charakter procesu produkcyjnego niedostatecznym popytem, nadmiarem oszczędności i brakiem inwestycji. Inna teza J. Keynesa na temat roli oczekiwań w gospodarce była rozwinięta R. Lucasem teorii racjonalnych oczekiwań, które $\mathrm{z}$ kolei powinno być podstawą nowoczesnych ekonometrycznych modeli funkcjonowania gospodarki rynkowej i przyczyniła się do przemyślenia polityki gospodarczej.

Szczególne miejsce w rozwoju teorii cykli należy do N. Kondratiewa, autora koncepcji "długich fal". "Wielkie cykle - napisał N. Kondratiew - możemy traktować jako naruszenie i przywracanie równowagi gospodarczej $\mathrm{w}$ długim okresie. Główna przyczyna leży $\mathrm{w}$ mechanizmie kumulacji, akumulacji rozpraszania kapitału wystarczającego do tworzenia nowych sił wytwórczych" (Kondratiew, 1989). Naukowiec wyjaśnił przyczynowości powstawania długich cykli zmiany w podstawowych technologii, źródeł energii i obiektów infrastruktury, innymi słowami koniecznością aktualizacji kapitału podstawowego. W szczególności kryzys 1929-1933 r. potwierdził prognostyczną możliwość tej teorii, ponieważ sam N. Kondratiew przeznaczył dwie pełne długie fale i podnoszenie fazy trzeciej (jej długość z 1896 r. w 1920 r.). Więc faza spadku trzeciej fali akurat zbiegła się w czasie z ostatnim kryzysem. Nowoczesny podział długich fal obejmuje już pięć długich fal. Znaczący wkład w badanie przyniósła francuska szkoła "Anneli" i jej lider F. Braudel, który uzasadnił związek wiekowych trendów i cykli Kondratiewa.

J. Schumpeter przyjął doktrynę M. Kondratiewa i rozwijął ją w innowacyjną teorię, która później stała się podstawą współczesnej ewolucyjnej teorii (W. Majewski, R. Nelson, S. Winter). Cykliczny charakter wzrostu gospodarczego, zdaniem J. Schumpetera, ze względu na spazmatyczny charakter innowacji, który $\mathrm{z}$ kolei jest czynnikiem powstawania niedoskonałości konkurencji. Pomysły J. Schumpetera znalazły później odzwierciedlenie w wielu innowacyjnych koncepcji, w szczególności: teoria zaburzeń aktywności innowacyjnej H. Mensch'a, koncepcji technologicznej przepaści R. Fostera, koncepcji technologicznych styli D. Lwowa i F. Hayek'a, teorii gospodarki innowacyjnej i przedsiębiorczości społeczeństwa P. Druckera, itp.

$\mathrm{W}$ ostatniej trzeciej XX wieku, pod wpływem zmian w charakterze, dynamice i skali zjawisk kryzysowych wzmocniają się pozycji finansowych teorii cykli. H. Minsky, L. Ray, Ch. Wholen itp. skupili swoją uwagę na badaniu finansowych składników w publicznej produkcji. Wśród nowych teorii finansowych należy wyróżnić koncepcję finansowego wzrostu, ktora połączyła skutki azjatyckiego kryzysu lat 1997-1998 i akcelerator finansowy, opracowany przez grupę amerykańskich naukowców, na czele z B. Bernanke. 
Wśród innych klasyfikacji teorii cykli koniunkturalnych zasługuje na uwagę podejście W. Zarnowica, która opiera się na ich potencjalnych źródłach. Odpowiednio autor wyróżnia następujące modele cyklicznych wahań gospodarczych: modele cykli z "ściślymi okresowymi wahaniami" (N. Koldor, J. Hicks, R. Goodwin): modele cykli z ,grubymi wahaniami” (W. Jevons, J. Moore); model "politycznego cyklu koniunkturalnego" (W. Nordhaus, D. Ginb, A. Lindbeck, A. Zuckerman); modele z "wolnymi wahaniami" (R. Frisch i J. Hikmen, A. Blanchard, M. Watson).

\section{Zjawisko teorii cykliczności w warunkach globalizacji}

Kluczowym trendem rozwoju gospodarki światowej jest dynamizm integracyjnych i globalizacyjnych procesów, co w szerokim sensie oznacza tworzenie wspólnej gospodarczej przestrzeni. Globalizacja - to wzajemne zbliżenie państw i narodów, ich gospodarek i gospodarczych procesów penetracji technologii informatycznych, tworzenia wspólnej infrastruktury, integracja na poziomie regionalnych i światowych rynków, polityczna transformacja. Ją interpretują jako proces, który wywyższa cywilizację na wyższy stopień rozwoju w systemie internacjonalnych warunków i sfer ludzkiego życia, przejawia się w zwiększaniu efektywności rozwoju dzięki rozprzestrzenianiu się innowacji, synchronizacji tempa i poziomu gospodarczego wzrostu, socjalizacji stosunków gospodarczych, tworzenia wspólnej finansowo-gospodarczej przestrzeni, globalnej socjologiczno-kulturalnej unifikacji.

Jednak pomimo ekonomicznej korzyści z globalizacji większość naukowców uznaje, że jako obiektywny i całościowy proces ma kontrowersyjny, niejednoznaczny i falopodobny charakter. Wzrost spółzależności gospodarek narodowych, ich ekonomicznych procesów i podmiotów mają odwrotny skutek niezwykłą wrażliwość na procesy, które odbywają się w innych krajach i regionach świata. Ostatnie przejawia się w zaburzeniach równowagi gospodarki światowej, pogłębieniu asymetrii rozwoju społeczno-gospodarczego krajów, co ostatecznie kończy się coraz bardziej widocznymi zjawiskami depresji i kryzysów. Dowodem tego był kryzys gospodarczy lat 2008-2009, kiedy to właśnie globalizacja przyczyniła się do tak zwanego rozprzestrzeniania się "wirusa kryzysu", ponieważ to właśnie problemy amerykańskiej gospodarki wywołały zamieszanie w większości krajów na całym świecie.

Kryzys lat 2008-2009 znacznie różni się od swoich "poprzedników" i swoją ekscentrycznością poważnie zaniepokoił towarzystwo naukowe, postawił pod znakiem zapytania wypracowany zestaw narzędzi nauk ekonomicznych w badaniu cyklicznym. Jednocześnie kryzys zaktywizował uwagę naukowców i badaczy, polityków i osób publicznych, poglądy których co do jego oceny są zasadniczo różne, ale łączą się w uznaniu jego globalnej skali.

Czy ten kryzys jest pierwszym globalnym, czy jest na liscie globalnych zawirowań społeczeństwa? Odpowiedź na to pytanie zależy od zrozumienia chronologicznych ram globalizacji. Istnieją dwa podejścia do ich identyfikacji. W ramach pierwszego podejścia globalizacja traktowana jest jako długi historyczny proces stopniowego kształtowania jednolitości W skali planety, który towarzyszył procesu cywilizacyjnego rozwoju. Przedstawicielami drugiego podejścia globalizacji jest postrzegana jako najnowsze zjawisko, które staje się charakterystycznym w ostatniej trzeciej części XX wieku.

Odpowiednio do koncepcji pierwszego podejścia, właściwe są tezy dotyczące identyfikacji czterech globalnych kryzysów rozwoju: 
pierwszy - socjobiosferny kryzys, miał miejsce w ciągu 25-10 tys. lat p.n.e. i był spowodowany globalnymi zmianami w stanie światowego klimatu;

drugi - kryzys starożytności, który trwał w ciągu 4-6 st. i zakończył się upadkiem cesarstwa Rzymskiego;

trzeci - kryzys feudalizmu (1453-1648 r.), którego efektem jest kształtowanie się nowoczesnych państw;

czwarty - nowoczesny, w którym, z kolei, wyróżniają dwa etapy:

I etap - 1873-1933 r.;

II etap - 2008 i teraz.

Warto zwrócić uwagę, że pierwszy etap czwartego globalnego kryzysu kończy się Wielkim kryzysem (1929-1933 r.) wraz z pojawieniem nowych ekonomicznych prądów (takich jak keynesizm) i podstawowych pojęć nowoczesnego, ekonomicznego układu, nowego instytucjonalnego systemu, ruchami społecznymi, korporacjami międzynarodowymi. Drugi zaczyna się od kryzysu lat 2008-2009, ma oznaki kryzysu cywilizacyjnego, i przejawia się w ciśnieniu jednej cywilizacji na inne, zniknięciem protestanckiej moralności, pojawienie się kultu konsumpcji.

W ramach drugiego podejścia kryzys lat 2008-2009 jest oceniany jako pierwszy globalny kryzys lub jako pierwszy kryzys epoki globalizacji. To właśnie ten punkt widzenia na dzień dzisiejszy jest dominujący, choć jego potencjał kształtował się w ciągu ostatniej dekady XX wieku. (chodzi o azjatycki kryzys finansowy w latach 1997-1998). Liczne badania kryzysu lat 2008-2009 różnią się określeniem jego przyczyn, tła, charakteru, przebiegu i skutków opartych na pozycji różnych kierunków i szkół nauk ekonomicznych, w szczególności: neoklasycznej szkoły, keynesizmu, instytucjonalizmu, behawioralnej teorii, itp. Usystematyzowanie poglądów na naturę globalnego kryzysu lat 2008-2009 zawarte w tabeli (1).

Dostępne podejścia do interpretacji natury kryzysu lat 2008-2009 potwierdzają fakt, że logika jego powstania i przebiegu jest zgodna z ustalonymi koncepcjami rozwoju gospodarki rynkowej i/lub jest następstwem błędów polityki państwowej. Dlatego w problematyce współczesnego kryzysu trzeba prześledzić proces akumulacji kapitału, ale polem jego działalnością stają się rynki finansowe, gdzie on może się rozwijać bez procesu produkcji przemysłowej. Zgodnie z logiką rozwoju wielkich cykli, na początku XXI wieku światowy system gospodarczy wszedł w przełomowy moment piątego wielkiego cyklu M. Kondratiewa, konsekwencją czego stały się przede wszystkim strukturalne sprzeczności, determininują się naukowo-technicznych czynnikiem, i oczekują jego rozwiązania poprzez przejście do szóstego technologicznego sposobu życia. Potwierdzeniem pomysły synchronizacji cykli o różnej długości jest fakt, że scenariusz rozwoju kryzysu w latach 2008-2009 wykazuje oznaki średnioterminowego cyklu C. Juglara: przegrzanie gospodarki, spekulacje finansowe, nagłe zawalenie.

Jednakże, głębokość i zakres wpływu na gospodarki narodowe ostatni kryzys wykracza poza tradycyjny charakter cykliczny, charakteryzuje się obecnością poważnych różnic i cech w stosunku do poprzednich, warunkowane przez paradygmatyczne zmiany w rozwoju społeczno-gospodarczym. Globalna gospodarka jest historycznie nową rzeczywistością, która różni się od tradycyjnej gospodarki światowej. Według M. Castelli: „Globalna gospodarka jest coś innego: to gospodarka, która ma zdolność do pracy jako jeden system w czasie rzeczywistym w skali całej planety" (Castells, 2000:105). 
Tabela 1

Usystematyzowanie poglądów na naturę kryzysu lat 2008-2009

\begin{tabular}{|c|c|c|}
\hline Autorzy & Teoria & Treść teorii \\
\hline Jacques Attali & Asymetria informacji & $\begin{array}{l}\text { Informacje szerzą się na całym świecie zbyt } \\
\text { nierównomiernie, asymetria informacji jest } \\
\text { zawsze obecna między teraźniejszością a } \\
\text { przyszłością. To powoduje katastrofy } \\
\text { gospodarcze, w szczególności nadwyżkę } \\
\text { podaży }\end{array}$ \\
\hline $\begin{array}{c}\text { George Soros, } \\
\text { Wiaczesław Jusim }\end{array}$ & $\begin{array}{c}\text { Koncepcja } \\
\text { refleksyjności }\end{array}$ & $\begin{array}{l}\text { Zjawiska społeczne często zawierają element } \\
\text { niepewności, który jest uwarunkowany } \\
\text { zarówno obiektywnymi prawami } \\
\text { rzeczywistości, jak i myślą ludzi o konkretnej } \\
\text { sytuacji. Brak wiedzy jest kompensowany } \\
\text { przez myśli, to znaczy domysły, hipokryzję. }\end{array}$ \\
\hline Giovanni Arrighi & $\begin{array}{c}\text { Systemowy cykl } \\
\text { akumulacji kapitału } \\
\text { (kapitał spekulatywny) }\end{array}$ & $\begin{array}{l}\text { Systemowy cykl składa się z fazy ekspansji } \\
\text { materialnej i fazy ekspansji finansowej. } \\
\text { Kryzys akumulacji kapitału prowadzi do } \\
\text { długich okresów ekspansji finansowej, } \\
\text { zwłąszcza tam na dużą skalę wdraża się rynek } \\
\text { giełdowy, rynki finansowych instrumentów } \\
\text { pochodnych i zobowiązania dłużne, co } \\
\text { zwiększa kapitał spekulacyjny. }\end{array}$ \\
\hline Sergey Glazyev & $\begin{array}{c}\text { Koncepcyjne pojęcie } \\
\text { długoterminowego } \\
\text { rozwoju gospodarczego }\end{array}$ & $\begin{array}{l}\text { Zestaw technologicznych procesów } \\
\text { produkcyjnych generuje synchroniczność w } \\
\text { ewolucji produkcji, która tworzy ich } \\
\text { integralnośc reprodukcyjną, która tworzy } \\
\text { materialną podstawę cyklicznych oscylacji. }\end{array}$ \\
\hline $\begin{array}{c}\text { Dmytro } \\
\text { Lukjanienko, } \\
\text { Anatolij Porucznyk i } \\
\text { inne }\end{array}$ & $\begin{array}{l}\text { Globalny cykl } \\
\text { gospodarczy }\end{array}$ & $\begin{array}{l}\text { Kryzys globalny może mieć polityczne, } \\
\text { ekonomiczne warunki wstępne, ale nie może, } \\
\text { ze względu na swój charakter, być } \\
\text { funkcjonalny } \\
\text { zdeterminowany lub }\end{array}$ \\
\hline
\end{tabular}

Według: (Kornejczuk, 2010; Głazjew, 2009; Łukjanienko, Porucznik i inne, 2008)

Ponieważ jedna z definicji kategorii "kryzys" traktuje go jak wyzwanie na zaostrzenie się sprzeczności w rozwoju systemu społeczno-gospodarczego, zagrożenia jego funkcjonowaniu, to i przyczyny globalnego kryzysu należy identyfikować w naturze globalizacji, analizie jej sprzeczności, słabych stron i niepowodzeń. Wśród tych podstawowych sprzeczności globalizacji naukowcy podkreślają rosnącą globalną nawarstwianie, pogłębienie antagonizmów między klasami biednych i bogatych obywateli w planetarnej skali. O zagrożeniu ostrzegał P. Sorokin, biorąc pod uwagę, że istnieje punkt nasycenia gospodarczej stratyfikacji, dalej którego społeczeństwo nie może przejść bez ryzyka poważnej katastrofy" (Sorokin, 1992). Od 1960 do 1980 roku nierówność charakteryzowała się stabilnością, co oznaczało brak szybszego lub wolniejszego systematycznego wzrostu biednych lub bogatych krajów. Różnice zaczęły się od 1980 r., kiedy rozpoczęły się procesy globalizacji i wzrost bogatych krajów stał się wyprzedzać wzrost biednych. Rosły nierówności wewnątrz poszczególnych krajów, jak wynik z 1980 po 
2016 r. na 1\% najbogatszych w świecie osób spadła o połowę większa część wzrostu przychodów niż 50\% najbiedniejszych (Alvaredo, Chancel, Piketty i inne, 2018).

Drugą sprzecznością globalizacji jest technoglobalizm, co przejawia się w technologicznym zróżnicowaniu, istnieniu gospodarek narodowych w ramach różnych technologicznych ustrójow. Kraje rozwinięte wykazują dziś przejście do szóstego technologicznego sposobu życia, który jest bardziej znany jako czwarta rewolucja przemysłowa (C. Schwabe). Jego podstawę stanowią nanotechnologii i inżynierię komórkową $\mathrm{i}$ to właśnie dzięki utworzeniu klastra poważniejszych innowacji niniejszego układu, w ramach cykli S. Kuzetsa i S. Kondratiewa, gospodarka światowa począwszy od 2020 r. może przejść na narastającą falę kolejnego cyklu. Ostatnie prognozy rozwoju na świecie do 2025 roku od Centralnej Agencji Wywiadowczej, CIA wskroś przeniknięte innowacjami. Jednak innowacje jako kluczowy warunek sukcesu gospodarczego są dostępne dla coraz mniejszego grona krajów.

Fenomenem współczesnej gospodarki światowej stało się rozdzielenie w jej ramach podsystemu globalnych finansów, co przejawia się w wyprzedzającym wzroscie światowego rynku finansowego $\mathrm{w}$ porównaniu $\mathrm{z}$ rynkiem produkcji, pogłębienie zaburzeń akumulacji produkcyjnego i finansowego (spekulacyjnego) kapitału, wzrost wirtualizacji operacji finansowych. Siłą napędową kryzysu lat 2008-2009 było sztuczne "zawyżanie" funkcji sektora finansowego $\mathrm{i}$ oderwanie go od realnej gospodarki, gospodarki w produkcji i sprzedaży dóbr i usług. Stając dialektycznym przeciwieństwem finansowy i prawdziwy sektory gospodarki światowej spowodowały zerwanie między przepływem środków finansowych i ich materialnymi nośnikami. Tak właśnie powstał mechanizm transmisji zjawisk kryzysowych na globalnym obszarze gospodarczym.

Warto zwrócić uwagę na jedną podstawową przesłankę współczesnego globalnego kryzysu - to rynkowy fundamentalizm, który opiera się na dominującej obecnie w ekonomii i polityce neoliberalnej doktryny. Część społeczności naukowej najbardziej nastrojónej reformistski w stosunku do modelu gospodarki sprzed kryzysu i jej teoretycznych podstaw, uważa, że kryzys ma endogeniczne pochodzenie i został wywołany przez żywiołowe siły rynku, które zintensyfikowane dzięki polityce deregulacji życia gospodarczego rozpoczętego w latach 1980-1990. Deregulacja biznesu i finansów, rezygnacja z państwowego makroekonomicznej regulacji, prywatyzacja usług publicznych i przedsiębiorstw, zmniejszenie świadczeń socjalnych, zwiększenie nacisku na związki zawodowe stały się dowodami przejścia systemu gospodarczego do neoliberalnej instytucjonalnej struktury. Szczególnie groźne stała się liberalizacja sektora finansowego w warunkach stałego wzrostu międzynarodowej mobilności kapitału, co udowodnił kryzys lat 2008-2009, ostrzejszy uderzając narodowe gospodarki, których rynki finansowe były bardziej zintegrowane w globalny rynek kapitałowy.

Soros podkreśla, że "...głęboko i beznadziejnie błędne jest i nowoczesny model globalizacji, który w swej istocie jest raczej globalizacją dla siebie, dla jej poszczególnych podmiotów, a nie globalizacją dla wszystkich" (Soros, 1999: 24).

Rynkowy fundamentalizm jest, w rzeczywistości, teoretyczną i ideologiczną podstawą globalizacji w ogóle. Oznacza to, że czysto rynkowe zasady odnoszą się do wszystkich bez wyjątku segmenty życia społecznego, obejmują nie tylko gospodarcze, ale i polityczne, społeczne i duchowe elementy życia społeczeństwa. To może grozić nie tylko utratą wartości cywilizacyjnych, stylu życia i myślenia każdego pojedynczego człowieka, ale i istnieniu globalnego systemu gospodarczego. 


\section{Wnioski}

Istniejące koncepcje teoretyczne cykli są oparte na doświadczeniu przebiegu poprzednich gospodarczych kryzysów, podczas gdy przesłanki kolejnych zjawisk kryzysowych, jak zwykle, się zmieniają. To potwierdza tezę, że takich samych kryzysów nie ma, a to oznacza, że ich badanie obejmuje zarówno korzystanie z nabytego gospodarczej nauką instrumentacji, jak i poszukiwanie nowych podejść teoretycznych. Przeprowadzone uogólnienie teorii cykli przekonuje, że większość znanych teorii zawierają podstawowe przepisy, które nie tylko nie są ze sobą sprzeczne, a zastosowanie których jest niezbędne i możliwe do dalszych badań.

Kryzys lat 2008-2009 zidentyfikowano jako globalny, ponieważ zjawiska kryzysowe poruszają się i rozprzestrzeniają się na wszystkie kraje, które są zawarte w międzynarodowe stosunki gospodarcze, następuje synchronizacja cykli gospodarczych różnych krajów. Jego podstawą są jak klasyczne elementy ekonomicznych cykli, jak i nowe, co jest wynikiem niezgodności samych procesów globalizacji. Największy wpływ na dojrzałość zjawisk kryzysowych w gospodarce światowej mają procesy technologicznej i finansowej globalizacji, planetarna stratyfikacja społeczna, globalna monopolizacja kapitału i przemysłu.

Współczesny kryzys jest identyfikowany jako systemowy, ponieważ zjawiska kryzysowe objęły nie tylko realny i finansowy sektory, ale i społeczną, polityczną, duchową sferę, naturalne środowisko, kulturę itp. Nie ostatnią rolę w tym odegrał rynkowy fundamentalizm, który stał się dominującą teoretycznej i ideologicznej koncepcją globalizacji.

Kryzys ujawnił "wąskie" miejsca globalnego instytucjonalnego systemu, udowodnił, że on teoretycznie i praktycznie nie jest gotowy do wprowadzenia systemowych środków antykryzysowych, nie może dać odpowiedź na współczesne globalne wyzwania. Niestety i konsekwencją globalnego kryzysu gospodarczego nie stała się zasadniczą przebudową systemu międzynarodowych stosunków gospodarczych. Póki co można stwierdzić, że system próbuje utrzymać istniejącą walutowo-finansowy system poprzez jego częściowe ulepszenia, a to oznacza, że gospodarka światowa ryzykuje akcją kolejnego globalnego kryzysu.

\section{References}

Alvaredo, F., Chancel, L., Piketty, Th. And others. World Inequality Report. (2018). World INEQUALITY Lab. [in English].

Castells, M. (2000). The Information Age: Economy, Society and Culture. Oxford, UK: Blackwell. [in English].

Glaz'ev, S. 2009. World economic crisis as process of change of technological ways. Voprosy ekonomiki, no. 3, 26-38. [in Russian].

Kondratiew, H. D. (1989). The problems of economic dynamics. Moscow: Econimy. [in Russian].

Kornejczuk, B. W. (2010). Economists on the causes of the crisis. The Economist, no. 5, 1926. [in Russian].

Lukyanenko, D. G, Poruchnyk, A. M, Kolot, A. M. (2008). The global economy of the XXI Century: The Human Dimension. [Monograph]. Kiev: KNEU. [in Ukrainian].

Osipow J. M. (2008). The financial economy as the highest form of the economy's economy. Philosophy of the economy, no. 6, 32. [in Russian].

Sorokin, P. (1992). Human. Civilization. Society. - Moscow: Polytyzdat. [in Russian].

Soros, J. (1999). The Crisis of Global Capitalism: Open Society Endangered. Kyiv: Osnowy. [in Russian]. 